\title{
PERFORMANCE ACCOUNTABILITY: A STUDY OF THE UK AND IRISH CHARITY PRACTICES AT A TIME OF CHANGE
}

\author{
Ciaran Connolly, Noel Hyndman and Mariannunziata Liguori \\ Queen's Management School, Queen's University Belfast
}

\begin{abstract}
$\mathrm{T}$

The charity sector has major economic, cultural and social impacts on society. To maintain confidence and build trust, good accounting and reporting systems are essential. Indeed, such could be viewed as necessary conditions for the health and growth of the sector. Well-developed and appropriate accounting and reporting systems (particularly with respect to performance) can help charities discharge accountability to external stakeholders and establish legitimacy in wider society. This paper explores and compares performance reporting by large charities in the United Kingdom (UK) (which has a more-established regulatory architecture) and in the Republic of Ireland (RoI) (which has a much-less developed regulatory framework) at a time when new reporting regulations are being introduced. Through an analysis of the annual reports and annual reviews of 50 large charities, this paper highlights continuing weak performance accountability in both jurisdictions (especially in the RoI). The implications of this are discussed. It is argued that much has yet to be done by charities themselves, and by those concerned with the administration and control of the sector, to rectify this weakness and provide a foundation for better accountability, legitimacy and trust.
\end{abstract}

\section{INTRODUCTION}

The charity sector is quite different from either the private or the public sectors in terms of its orientation and motivation, the nature of its activities, its resource availability and the manner of its contribution to the public good. Regardless of their size, charities play a significant and vital role in society, often serving and assisting those who are most disadvantaged, marginalised or helpless. In both the United 
Kingdom (UK) and the Republic of Ireland (RoI), an organisation is considered to be a charity if its purposes are deemed to be 'charitable' and it fulfils a 'public benefit' (with the law in each jurisdiction specifying how such factors are determined). The charity sectors in the UK and RoI are significant socially and economically. In the UK, there are over 200,000 registered charities with an estimated total annual income approaching $£ 80$ billion (Charity Commission, 2016; Charity Commission for Northern Ireland (CCNI), 2017; Office of the Scottish Charity Regulator (OSCR), 2017). In the RoI, although it is more difficult to get accurate estimates of numbers and economic significance (partly because of a regulatory framework more in its infancy), Breen and Carroll (2015) suggest that there may be over 8,000 charities, which are a subset of a larger not-for-profit (NFP) sector of 12,000 organisations with an annual income of approximately $€ 6$ billion (approximately $£ 5.3$ billion).

The growth in the size and influence of the sector (Cabinet Office, 2002), combined with a number of highly publicised governance and fundraising scandals, has led to increased sector visibility and public scrutiny in both the UK and RoI (Burke-Kennedy, 2013; O'Brien, 2013; Hind, 2017). In particular, the need for the sector to operate transparently and discharge accountability appropriately has been widely articulated (Charity Commission, 2000a, 2005; Ebrahim, 2003; Accounting Standards Board (ASB), 2007; Breen and Carroll, 2015). Under the 2006 Charities Act, the Charity Commission in England and Wales (hereafter referred to as Charity Commission) has been charged with the responsibility to enhance charitable accountability, increase public trust and confidence and also promote the effective use of charitable funds. In Scotland and Northern Ireland (NI), major changes in the regulatory environment have emphasised similar themes. In the RoI, the Department of Justice, Law Reform and Equality is responsible for charity regulation. The Charities Regulatory Authority (CRA) was established in October 2014, with a key task being to improve the accountability and transparency of the sector.

Accountability can be viewed as being related to the requirement to be answerable for one's conduct and responsibilities. A key argument is that good accountability by charities supports building of trust, and trust is essential to ensure the health of the sector (including its ability to access funding). While accountability is wider than accounting (no matter how widely we define accounting), good accounting and reporting are key aspects of a good system of accountability. With regard to accountability, two key questions emerge: to whom is a charity accountable; and for what is a charity accountable? Reflecting ideas from both agency theory as related to charities (Laughlin, 1990) and Mitchell, Agle and Wood's (1997) theory of stakeholder identification and salience, it can be argued that donors (including funders) is a key upward stakeholder group to whom an account is owed. Donors/funders provide resources to a charity and often receive no direct economic benefit in return; without their support, charities cannot function and charitable activity will cease. In terms of the form of the account, it has been argued that while financial accountability (possibly through audited financial statements) is important (e.g. to indicate that the money raised has been used for the appropriate purposes and that the charity has 'lived within its means'), such accounts are likely only to be of secondary importance to donors/funders (and other important stakeholders) (Gray, 1983). Other wider information, particularly relating to performance, is likely to 
be paramount in discharging accountability, and this will require the telling of 'the story' of the charity in a way that is truthful, consequential and engages with them (Boyne and Law, 1991; Stone and Ostrower, 2007; Connolly and Hyndman, 2013).

The widespread adoption of appropriate accounting and reporting practices, and the ongoing renewal of such, has the potential to support charities in discharging accountability, particularly to donors/funders. A vital aspect of this has been the evolving development of a Statement of Recommended Practice (SORP) $)^{1}$ for charities. Over time, through its various iterations, the SORP, which consists of financial statement and trustees' annual report (TAR) requirements, ${ }^{2}$ has increasingly emphasised the importance of performance information both in discharging accountability and as a basis for sharpening mission focus (Hyndman and McConville, 2018).

Reflecting a differential jurisdictional focus on the regulation of charities, most UK charities have had a charity regulator since the 19th century, while the CRA in the RoI was only established recently (2014). Indeed, possibly reflecting this, compliance with the SORP is a legal requirement for the largest UK charities ${ }^{3}$ (including all of those in this study), although only best practice for RoI charities. Against a backdrop of high-visibility governance and fundraising scandals, new accounting and reporting guidance and emerging legislative adjustments, the objective of this paper is to explore performance reporting by large charities in each jurisdiction in the light of the literature on accountability and stakeholder theory. This study offers a twofold theoretical contribution. Following stakeholder theory, it suggests that charities perceive key stakeholders (including donors/funders and the general public) as particularly interested in the activities they carry out, rather than in 'cold' numbers measuring their efficiency and effectiveness; hence, a focus on more descriptive information relating to performance is provided in charities' reports. Moreover, the results hint that having a mandatory reporting system in place potentially increases the likelihood of more general disclosure. This is evident in the case of the UK when compared to the RoI. The paper begins by discussing charity accounting and accountability, with a particular emphasis on performance reporting. This is followed by an overview of the changing landscape with respect to the accountability of charities in the UK and RoI; here, prior, related research is also presented. Then, after explaining the research methods, the results are reported and discussed. A key contribution of this paper is that it highlights continuing weak performance accountability in both jurisdictions (especially in the RoI). It is argued that much has yet to be done by charities themselves, and by those concerned with the administration and control of the sector, to rectify this weakness and provide a foundation for better accountability, legitimacy and trust. It is contended that such is necessary if the development of the sector is to be encouraged, and the ongoing health of it is to be safeguarded.

\section{FINANCIAL AND PERFORMANCE ACCOUNTABILITY}

\section{Accounting and Accountability}

Conventional views of accounting see it as a purposive activity, directed towards a specified end, which is the meeting of users' (or stakeholders') information needs, with a stakeholder being defined as any 'group or individual who can affect or is 
affected by an organisation's achievements' (Freeman, 1984, p. 46) (e.g. beneficiaries, donors/funders, regulators or the public at large). It is viewed as being concerned with providing information to satisfy the needs of users/stakeholders (Accounting Standards Committee (ASC), 1975; ASB, 1999), and interpretations of this in the context of not-for-profit organisations (NFPOs) (ASB, 2007) highlight a similar thrust. Accountability can be viewed as being related to the requirement to be answerable for one's conduct and responsibilities; a concept that comes more into focus when faced with a changing and dynamic external environment (e.g. influenced by high-profile scandals and changing legislative frameworks). While accountability is more than accounting, good accounting and reporting are key aspects of a good system of accountability (Jackson, 1982).

In the context of charities, the Charity Commission (2004a, p. 2) sees accountability in terms of a charity's response to the legitimate information needs of its stakeholders, an aspect of which is often made through annual reports that should provide 'adequate information to allow stakeholders to assess the overall performance of the charity'. Emphasising a wider perspective, Roberts and Scapens (1985, p. 447) describe accountability as a relationship where parties explain and take responsibility for their actions through 'the giving and demanding of reasons for conduct'. In a similar light, Fry (1995, p. 184) views accountability in terms of 'public account-giving' that might include 'justifications, rationalisations, stories, excuses'.

This accountability relationship (or stakeholder/user-needs model) can be seen as a principal-agent association (reflecting ideas connected to agency theory) whereby a principal transfers resources to an agent and has expectations regarding the transfer. This forms the basis of an accountability relationship, and as Laughlin (1996) highlights, these expectations are complex and may be written and explicit or unwritten and implicit. In a charity context, the principal could be viewed as a donor or major funder (often considered a key stakeholder) who transfers resources (without any direct economic benefit to themselves anticipated) to an agent (the charity). With such a transfer, comes expectations (frequently not specifically detailed in anything resembling contractual terms) on the part of the donor/funder (principal) that the resources will be used to further the mission and objectives of the charity (often expressed in terms of supporting beneficiary need, or creating a wider public benefit); and expectations that information will be provided regarding what a charity has done or plans to do (possibly in terms of activities, stories, plans and spending). Accountability is discharged (or an account is given) as such information is communicated (through a variety of mechanisms and channels) to the donor/funder (principal) regarding this. On this basis, the principal (donor/ funder) holds the agent (the charity) to account by responding to such information through action (e.g. continuing to provide funds or ceasing to provide funds) or communication (e.g. by congratulating or censoring the charity).

In considering the accountability, two key questions emerge: to whom is a charity accountable; and for what is a charity accountable?

\section{To Whom Is a Charity Accountable?}

Several authors have identified (or speculated about) the stakeholders who, in the language of Freeman (1984), are 'affected' or 'affect' the operation of NFPOs 
(including charities) (Hyndman and McDonnell, 2009). In these studies, the key external stakeholders identified include: beneficiaries, government and regulators, donors/funders and the public at large. Given the breadth of parties who might be considered stakeholders, the issue of how organisations can identify 'who or what really counts' and prioritise competing stakeholder claims is considered by Mitchell et al. (1997, p. 853). They argue that the salience of stakeholders (or the degree to which they and their arguments are perceived to count) depends upon the stakeholder possessing three attributes: power, legitimacy and urgency. It is suggested that the most salient to the organisation are the stakeholders who are perceived to have the greatest amount of these attributes and that the claims of these 'definitive stakeholders' (p. 878) are likely to be prioritised. For charities, the language of stakeholder theory resonates with the Charity Commission's advocacy of needing to report to meet the information needs of stakeholders (Charity Commission, 2004a); developing good relationships with stakeholders as one of the Hallmarks of an Effective Charity (Charity Commission, 2004b); and involving key stakeholders in governance, such as including beneficiaries on boards of trustees (Charity Commission, 2000b).

By being accountable to donors/funders and regulators (upward stakeholders), possibly by focusing on financial probity, efficiency and impact on beneficiaries and societies, charities can gain external legitimacy from such parties (Ebrahim, 2003; ASB, 2007). This has become increasingly important as charities are being placed under growing scrutiny and the need to maintain (or reinstate) public trust and confidence, either voluntarily or on demand, is particularly emphasised (Hind, 2017). To an extent, charity donors/funders are somewhat akin to shareholders of commercial organisations (ASB, 2007). Yet while donors/funders are arguably less likely to monitor charities as closely as shareholders may commercial organisations, they are more likely to terminate their support if their trust and confidence wane as their personal welfare is not dependent upon this support. Accountability and transparency are, therefore, critical attributes through which to gain and maintain donor/funder support and trust.

In contrast to upward stakeholders (such as donors/funders), downward stakeholders (such as beneficiaries) may possess little power. However, reflecting an egalitarian ethical stance that may be present in charities, this should not necessarily result in limited and weak accounting to beneficiaries. Rather, it could be argued that recognising the weak position of downward stakeholders, charities (as value-driven organisations) should choose to prioritise them in the discharge of accountability. In addition, accounting to and for downward stakeholders enables charities to develop intangible sources of external legitimacy such as credibility, reputation, trust and integrity, which, in turn, are likely to engender the trust and support, not only of beneficiaries, but also of donors/funders (Connolly and Hyndman, 2017). In other words, consistent with the notion of a broad accountability paradigm, charities have an 'upward' accountability to their donors/funders and financial supporters, government and oversight agencies and the public at large, and also a 'downward' accountability to the beneficiary groups and clients who use their services. 


\section{For What Is a Charity Accountable?}

While Stewart (1984, p. 16) recognises that 'the purpose of the account and hence the basis of accountability can vary'; he argues that an accountability information system should report on a number of levels of accountability. Two main types of information (or types of accountability) that may be particularly important in this regard with respect to charities are: (i) financial information as contained in traditional financial reports (e.g. to indicate the sources of funding and the nature of expenditure) and (ii) wider performance information, often of a non-financial nature (possibly relating to the goals, objectives, output, impact, efficiency and effectiveness of the charity). Regarding accountability, the information needs, and desired engagement (if any), of each stakeholder group (e.g. beneficiaries/users of services, regulators and donors/funders) is likely to be different. For example, beneficiaries (and possibly donors/funders) may emphasise the output, or effectiveness, of a charity, while the concern of regulators may be more on efficiency and probity.

It has been suggested by several writers that, with charities, there may be temptation to focus accountability reporting on traditional financial accounts (and providing a 'financial' account) at the expense of wider performance reporting (and a 'performance' account). This is possibly because of the existence of standard rules and templates relating to a 'financial' account and the fact that accountants (who are often central to the information-provision process) may be particularly 'comfortable' and 'familiar' with such accounts. In addition, the determination of what is appropriate performance information (and the capturing of this information in an objective manner) is much more contestable and difficult than well-established financial interpretations. However, it has been argued that such a focus might undermine accountability by concentrating on the less important (Gray, 1983; Connolly and Hyndman, 2013). Gray (1983, 1984), in particular, highlights this danger, arguing that financial accounts only fully discharge accountability in 'special cases', the best example of which is the business enterprise/shareholder relationship. He suggests that, with charities, such reporting can only go a small way towards supporting the discharge of accountability.

\section{Measuring Performance in a Charity}

Given the importance of performance and performance accountability, how can 'performance' be viewed in the context of NFPOs, including charities? With NFPOs, it is common to examine performance in terms of a production process. Details of the elements of a range of NFPO production-process models are presented in Table 1.

While there are no standardised definitions for the terms input, processes (activities), output and result/outcome/impact, the following explanation may aid understanding. Input relates to the resources used in providing a service (e.g. expenditure incurred and number of staff). Processes represent the activities undertaken by an organisation (e.g. number of visits made, number of cancer research projects funded). Output is the actual goods or services produced for consumption (e.g. number of children fed, number of cancer research projects completed). Result (or outcome/impact) is concerned with the effect of an organisation's activities on individual beneficiaries and society more widely (e.g. change in the level of education, overall level of satisfaction with the services provided). While these 
TABLE I: ELEMENTS OF THE PRODUCTION PROCESS IN NOT-FOR-PROFIT ORGANISATIONS

\begin{tabular}{|c|c|c|c|c|c|c|}
\hline $\begin{array}{l}\text { Brace } \\
\text { et al. } \\
(1980)\end{array}$ & $\begin{array}{l}\text { American } \\
\text { Accounting } \\
\text { Association } \\
(1989)\end{array}$ & $\begin{array}{c}\text { Carter } \\
\text { et al. } \\
\text { (1992) }\end{array}$ & $\begin{array}{l}\text { Connolly } \\
\text { and } \\
\text { Hyndman } \\
(2003)\end{array}$ & $\begin{array}{l}\text { The W. K. } \\
\text { Kellogg } \\
\text { Foundation } \\
(2004)\end{array}$ & $\begin{array}{c}\text { Connolly } \\
\text { and Dhanani } \\
(2009)\end{array}$ & $\begin{array}{c}\text { Breckell } \\
\text { et al. } \\
(201 \mathrm{I})\end{array}$ \\
\hline Input & $\begin{array}{l}\text { Cost and } \\
\text { Input }\end{array}$ & Input & Input & Resources / Input & Input & \\
\hline Process & & Process & Process & Activities & & \\
\hline Output & Output & Output & Output & Output & Output & Output \\
\hline Result & Outcome & Outcome & $\begin{array}{l}\text { Outcome / } \\
\text { Result }\end{array}$ & $\begin{array}{l}\text { Outcome / } \\
\text { Impact }\end{array}$ & Result / Impact & $\begin{array}{l}\text { Outcome / } \\
\text { Impact }\end{array}$ \\
\hline
\end{tabular}

stages of the 'production process' are represented as being distinct, in reality there may be some blurring at the edges. Difficulties, for example, may arise in distinguishing between an output and result (outcome/impact) in certain circumstances. For convenience, the term 'impact' will be used throughout the remainder of this paper (rather than result or outcome).

Notwithstanding such difficulties, it is clear that the term 'impact' has, of late, gained particular providence and usage. For larger funders (and particularly those commissioning public services), such information is demanded as a basis for the targeting of resources at proven solutions to social problems (Lumley et al., 2011). In addition, the UK government has highlighted the importance of focusing on societal impact in government decision-making, and, in particular, when funding nongovernment organisations in the delivery of social programmes (HM Treasury, 2011). The UK government has also funded a cross-sector group known as 'Inspiring Impact', which seeks to encourage and support good practice in reporting on impact (Lumley et al., 2011) and has developed a Code of Good Impact Practice (Inspiring Impact, 2013). Interestingly, as mentioned earlier, the extant SORP (Charity Commission and OSCR, 2014) encourages impact reporting in the TAR.

Given this production process, it can be argued that the two key criteria for judging performance are efficiency (the ratio of output to input) and effectiveness (the relationship between an organisation's impact, or activities/output, and its objectives). An example of an efficiency measure for a charity might be the cost (an input) per child fed (an output), or the number of cases handled (an output) per employee (an input). A measure of effectiveness could be the number of children fed versus the planned number, or the decrease in blindness in a particular area versus the planned decrease as a result of a particular intervention. Often these criteria are used in a comparative, rather than an absolute sense. For example, it is not normally said that an organisation is 90 per cent efficient, but rather that it is more (or less) efficient than a comparable organisation, than it was last year or than budgeted for. A representation of a performance model that brings together the elements of the production process and relates them to the two key performance criteria (efficiency and effectiveness) is shown in Figure 1.

There are two key reasons for measuring performance in a charity. Firstly, performance measures can form the basis for discharging accountability (and help build connections with key stakeholders; this may be vital in establishing external 
FIGURE I: THE PRODUCTION MODEL

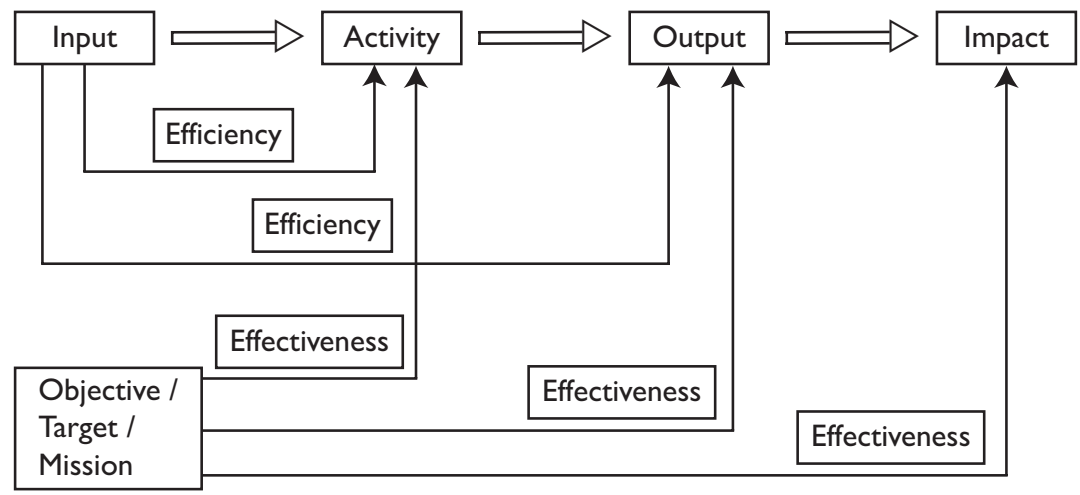

legitimacy), which is the focus of this paper. Secondly, it can provide essential information to improve management planning and control systems within the organisation. These two reasons interconnect. For example, in the public sector, it has been argued that the external pressure provided by the need to disclose performance information externally frequently encourages a focus on performance by management and provides a catalyst for performance improvement (Eden and Hyndman, 1999). Similar claims are relevant to the charity sector. Indeed, the external reporting of performance information by charities can provide a visibility to the activities and achievements of the organisation, enabling informed discussion (and decision-making) on the part of stakeholders. Moreover, the potential benefits of developing linkages between the use of performance information in a charity's planning and control system and the discharge of performance accountability are unmistakable (Hyndman and Anderson, 1997; Anthony and Young, 2002), with a clearly articulated and performance-focused planning and control framework supporting the discharge of accountability (Charities Aid Foundation, 2001; Charity Commission, 2004a, 2004b).

Although the need to develop appropriate performance measures in charities is well founded (Connolly and Dhanani, 2009; Nevill and Lumley, 2011; Charity Commission and OSCR, 2014; McConville, 2017), there are considerable difficulties in designing an information system which provides such information. For example, in many cases, mission and objectives are so vaguely drafted that they inhibit useful performance measures being developed (Williams, 1985). In addition, defining objectives in terms of activities, rather than impact related to the organisation's mission, can be problematic since more activity (and more expense) does not necessarily lead to more, or better, impact. Furthermore, aligning high-level and low-level performance measures is often challenging because of multiple (frequently competing) organisational goals, multiple stakeholder influences, unclear input-output relationships and the fact that many costs and benefits arise over the long term (Hedley et al., 2010; Nevill and Lumley, 2011). Moreover, whilst accepting that setting objectives is critical to performance measurement, there is a danger that, unless care is taken in developing useful systems (that are frequently refreshed), the process will degenerate into a formal ceremony that does little to improve charity accountability, efficiency and effectiveness (Thompson, 1995). 
It has been argued that accounting information should possess qualities such as relevance, objectivity, understandability, reliability and timeliness (ASB, 1999). Some of these characteristics pull in opposite directions and trade-offs are often required. For example, the price of improved relevance may be less objectivity, or the most reliable results may not be the timeliest. Thus, managers must exercise judgement in the selection of appropriate performance measures, with a particularly important issue being the comparability and reliability of information (Pendlebury et al., 1994). Whilst Mayston (1985) suggests introducing similar disciplines on the external reporting of performance information that are imposed on financial accounting information (e.g. disclosure requirements and external auditing), there are clear cost/benefit issues that have to be considered (Hedley et al., 2010; Hyndman and McConville, 2018). Notwithstanding the profound difficulties of measuring performance, not attempting to do so (no matter how contestable the resulting measures may be) can significantly undermine the strategic focus of the charity and weaken the discharge of accountability.

\section{CHANGING ACCOUNTING AND ACCOUNTABILITY}

Despite the importance of good accounting and reporting to the charity sector, until the 1980s the framework for such was extremely weak (Goodman Committee, 1976; Austin and Posnett, 1979; Bird and Morgan-Jones, 1981). In the UK and RoI, regulation was much less developed than it is today, with the lone regulator at that time (only England and Wales had such a functionary) not focusing to any significant extent on the reviewing and monitoring issues relating to accounting, reporting and accountability. Charity law was diverse and had little to say about charity accounting and the publication of financial statements. While charities were often under an obligation to keep proper books of account and to prepare financial statements regularly, frequently such statements did not have to show a 'true and fair view' and were not required to be audited. While this was not the case with charities incorporated as limited companies (these being subject to the reporting requirements of the companies' Acts), in practice, the detailed application of accounting standards to the financial statements of such incorporation was commonly ignored (and auditors rarely commented on lack of adherence to such standards) because of misunderstanding and inertia (Austin and Posnett, 1979). Overall, in the UK and RoI, there was limited pressure to improve charity reporting from legislation, accounting standards, or an effective regulatory body, and wider reporting (such as that relating to governance and performance) was rarely on the agenda (Connolly and Hyndman, 2004; Breen and Carroll, 2015).

This has changed considerably in the UK in the 1980s, with the development (in 1988) and periodic 'refreshing' (in 1995, 2000, 2005 and 2014) of a SORP relating to charity accounting and reporting; a SORP that, over time, has become mandatory for most large UK charities, and best practice for RoI charities. This has emphasised both the important 'financial account' and, the arguably, even more important 'performance account' (or telling the charity story - Connolly et al., 2013). While the original SORP (ASC, 1988) largely sought to reduce diversity in charity financial 
statements (based almost entirely on applying business accounting principles), subsequent revisions required financial statements to be much more charity specific and focused attention on the content of narrative information (in recognition of its significance in discharging accountability).

As implied earlier, while financial reporting is a necessary aspect for a charity's accountability framework, it is often an insufficient discharge of accountability for many (if not all) stakeholders. Charities are set up to provide services to specific beneficiaries (or society at large), and donors provide resources to facilitate such provision with no expectation of direct benefit to themselves. Throughout the evolution of the charities SORP, there has been an increasing recognition of the importance of performance reporting. This, for example, is reflected in recent debate calling for charities to focus on (and report) their performance or impact, with this information being suggested as having potential to strengthen both upward accountability to donors/funders and downward accountability to beneficiaries (Benjamin, 2012; Connolly and Hyndman, 2013). Indeed, the importance of this has been particularly recognised in the latest SORP (the 'FRS 102 SORP') (Charity Commission and OSCR, 2014, para. 1.43) which, while clearly acknowledging the challenges, explicitly encourages charities to develop and use impact reporting in the TAR as a basis for discharging performance accountability:

In reviewing achievements and performance, charities may consider the difference they have made by reference to terms such as inputs, activities, outputs, outcomes and impacts, with impact viewed in terms of the long-term effect of a charity's activities on both individual beneficiaries and at a societal level. Charities are encouraged to develop and use impact reporting (impact, arguably, being the ultimate expression of the performance of a charity), although it is acknowledged that there may be major measurement problems associated with this in many situations.

As discussed, two main types of information that are particularly important in discharging accountability are financial information and wider performance information. Prior research examining charity accounting and reporting in the UK and RoI (most of which has focused solely in the UK) can be broadly categorised into studies that have investigated the quality of charity financial statements and disclosure patterns of information accompanying annual financial statements, particularly relating to performance. While these categorisations are a convenient way to present the material, many of the previous studies relate to both categories (and sometimes more widely as well).

With respect to the first, a number of studies have explored the extent to which charity financial statements comply with best-practice financial accounting recommendations (Bird and Morgan-Jones, 1981; Ashford, 1989; Gambling et al., 1990; Hines and Jones, 1992; Williams and Palmer, 1998; Connolly and Hyndman, 2000, 2001, 2002; Palmer et al., 2001). These studies are often based on the presumption that this is important to a range of stakeholders. Whether such accounts are of interest to stakeholders, including the public (evidenced by an extensive and interested readership), or whether such publications are in the public interest (whereby a few interested and equipped parties will/may explore the detail and highlight areas of concern), often dominates discussions. It is likely that although many stakeholders 
have limited interest (and probably understanding) of the technical detail of financial accounts, it is in the public (and wider stakeholder) interest that such accounts are produced and audited (and, at the very least, have the potential to be scrutinised by a limited number of informed and interested individuals).

Over time, the focus of much empirical work has shifted away from financial accountability (usually framed in terms of compliance with the extant financial requirements of the SORP) to accountability for performance. Here, the key recurrent idea is that good financial reporting is a necessary, but not sufficient, focus for accountability and that the provision of other wider information, particularly relating to performance, is paramount in discharging accountability to a range of stakeholders (Hyndman, 1990, 1991; Connolly and Hyndman, 2003, 2004; Connolly and Dhanani, 2006, 2009; Dhanani, 2009; Jetty and Beattie, 2009; Hyndman and McConville, 2016, 2018). Overall, the findings from previous research indicate that while the extent of performance reporting has increased over time, it remains poor (and particularly poor in the RoI) and there are significant shortcomings in terms of making such reporting transparent. It is argued that these inadequacies made assessing performance difficult for most users.

\section{RESEARCH METHOD}

While most forms of data reaching the public domain can be considered to be part of the accountability discharge function, and whilst acknowledging the importance of traditional financial statements (in discharging financial accountability), this research focuses on the disclosure of performance information contained in the annual reports (in the TAR section) and annual reviews (if one is published) of large UK and RoI charities. The annual report is a statutory document, often seen as the key official accountability document, the content of which is regulated and subject to independent monitoring. The annual review is a voluntary form of communication with external stakeholders which many charities prepare alongside their annual report as a means of both marketing the charity and discharging accountability to external stakeholders. It is frequently written in less formal language and includes a higher proportion of stories, photographs and figures than TARs. These two channels were chosen as suitable units of analysis because they are within direct managerial control (Guthrie and Parker, 1989) and also because they have a level of formality that goes beyond a marketing/publicity type document.

Utilising the classification of charities in terms of what they (primarily) do and who they (primarily) help, the following five broad categories of charitable activities were developed:

1. Medical/Health/Sickness

2. Medical Research

3. Overseas Aid/Famine Relief;

4. Animal Welfare

5. Wider Social Objects (Children/Poverty/Social Welfare) 
To identify the performance information made available publicly to charity stakeholders, 25 UK and 25 RoI charities were selected and their most recent annual reports and annual reviews (if one was published) were obtained from their website. In order to acquire a sample of UK charities, the Advanced Search Features available on the Charity Commission's website ${ }^{4}$ were used to select five large charities based upon the total income from each of the aforementioned five categories. As a similar facility is not available for RoI charities, this sample was drawn from the Boardmatch (2013) Charity 100 index. However, while the twenty-five RoI charities were selected, as it was only possible to obtain three RoI 'animal welfare' charities due to the number of such organisations represented on the index, additional charities from categories 1 and 2 above were selected (Table 2). Of the fifty charities selected, twenty (UK - 16; RoI - 4) prepared a separate annual review (or equivalent) document (Table 2).

TABLE 2: DOCUMENT CONTENT ANALYSIS SAMPLE

\begin{tabular}{lccccccc}
\hline & $\begin{array}{c}\text { Medical / } \\
\text { Health / } \\
\text { Sickness }\end{array}$ & $\begin{array}{c}\text { Medical } \\
\text { Research }\end{array}$ & $\begin{array}{c}\text { Overseas } \\
\text { Aid / Famine } \\
\text { Relief }\end{array}$ & $\begin{array}{c}\text { Animal } \\
\text { Welfare }\end{array}$ & $\begin{array}{c}\text { Wider } \\
\text { Social } \\
\text { Objects }\end{array}$ & $\begin{array}{c}\text { Annual } \\
\text { Report }\end{array}$ & $\begin{array}{c}\text { Annual } \\
\text { Review }\end{array}$ \\
\hline UK & 5 & 5 & 5 & 5 & 5 & 25 & 16 \\
Rol & 6 & 6 & 5 & 3 & 5 & 25 & 4 \\
Total & $1 /$ & 11 & 10 & 8 & 10 & 50 & 20 \\
\hline
\end{tabular}

As outlined earlier, it has been argued that focusing and reporting on performance is critical in discharging accountability to key stakeholders (particularly donors/funders), and the elements of disclosure highlighted in Figure 1 represent key aspects of such communications. In addition, it can be argued that other complementary information that can support the analysis and interpretation of performance measures, and provide context, may also be useful in discharging performance accountability. For example, it is suggested that charities should explain their objectives and the significant activities undertaken in pursuit of the achievement of those objectives (Lumley et al., 2011; Charity Commission and OSCR, 2014; McConville, 2017). Moreover, it has been advocated that future target information and information on any lessons learned from an analysis of past performance can complement such disclosures, particularly to enable stakeholders to assess both direction of travel and the challenges that a charity may face in delivering performance (Hyndman, 1990; Ní Ógáin et al., 2012).

Based upon the framework shown in Figure 1, supplemented by reflections on prior empirical research and other related argumentation, a checklist was developed $^{5}$ to capture the performance accountability disclosures. As Table 3 shows, nine separate categories of performance information were reported. The importance of these was identified from previous studies that explored the potential significance of performance disclosure to key stakeholders, largely drawing on ideas reflecting accountability frameworks and stakeholder theory (Ebrahim, 2003; Dhanani, 2009; Hyndman and McDonnell, 2009; Hyndman and McConville, 2018). It is argued that the disclosure (or non-disclosure) of these nine key performance items in the annual 
reports or annual reviews of charities is indicative of the extent to which performance accountability has (or has not) been discharged. In terms of 'how' the data was collected, the checklist was originally tested on a small sample of organisations and then revised accordingly to enable the collection of a complete, objective and reliable source of data that: (i) captured the disclosures provided in the TAR and annual review that could be classified as performance accountability; and (ii) produced an objective and reliable final coding instrument. Definitions and rules were developed for classifying the highlighted copy information in order to reduce the impact of subjectivity. The rules included: information presented in more than one way was only counted once (in its most detailed form); when there was an efficiency target and the actual achievement of efficiency was given, this was counted as a measure of efficiency only; and when there was a quality target and the actual achievement of quality was given, this was counted as a measure of effectiveness. This approach ensured that, as far as possible, terms were being used in the same manner for each charity. The research identified whether any information relating to each of the nine category types was disclosed, not the amount of disclosure by category type.

\section{RESEARCH FINDINGS}

The results of the analysis are presented in Table 3 and identify (by jurisdiction) the extent to which each of the suggested nine performance-related disclosures (detailed earlier, and indicative of a meaningful discharge of performance accountability) was routinely made available to stakeholders through the more-formal communication channel of the TAR, and the less-formal annual review channel. For each item of information, it reports the number (and percentage) of charities disclosing by jurisdiction (UK and RoI). Using chi-square tests, significant differences (at the 1 per cent and 5 per cent levels) relating to these disclosures between jurisdictions are also shown. ${ }^{6}$

Before examining the disclosure of the items individually (Table 3 items (a)-(i)), it is worth noting that the average percentage of the UK and RoI charities disclosing the nine items ((a)-(i)) in both TARs and annual reviews was relatively low, with the average overall disclosure rate of all nine information types being 49 per cent in both TARs and annual reviews (when the charities from each jurisdiction were combined). Comparing jurisdictions, while the overall average disclosure was similar for annual reviews (49 per cent vs. 50 per cent), it was higher for the UK charities (56 per cent) compared with RoI charities (42 per cent) with regards to the TAR. However, with respect to the seven items ((c)-(i)) of performance information (which generally were more at the measurable, or 'sharp' end, of the performance process), the average disclosure by the UK and RoI charities in the TARs and annual reviews was, on average, considerably lower. In other words, there was more substantial disclosure of descriptions of aims and the types of activities undertaken (in a non-measurable descriptive manner), but much less 'calculation' of performance.

With respect to the performance-related disclosures, when comparisons were made between jurisdictions, it is seen from Table 3 that, with TARs, the disclosure levels were greater for eight of the nine items in the UK charities. Only with respect 
to item (b), activities carried out, was the percentage of disclosing charities higher in RoI charities; and, in each jurisdiction there was almost total (96 per cent in the UK), or total (100 per cent in RoI), disclosure with respect of this item. More strikingly, when focusing specifically on the sharper measurement of performance, items (c) to (i) (the seven information types in the lower part of Table 3), it is seen that the UK charities were more likely to disclose in each case. For example, 80 per cent of the UK charities disclosed at least one output measure (item (d)) in their TAR, compared with only 44 per cent of RoI charities. When chi-square tests were carried out between jurisdictions, focusing on each individual information type separately, statistically significant differences (at either the 1 per cent or 5 per cent level) were identified in three cases (items (d) output, (e) impact and (g) effectiveness). Arguably, these disclosures could be viewed as some of the most important (or higher-level) performance-related indicators (see earlier discussion on performance reporting) and were much more prevalent in the UK TARs. With respect to annual reviews, the jurisdictional differences were less clear-cut. For example, while the disclosure rates of five of the nine information types were higher with RoI charities, the overall average disclosure rate was similar in each jurisdiction (Table 3). However, given that only four RoI charities produced an annual review (compared with sixteen UK charities), care must be exercised in interpreting the results with respect to such communication channels.

Particularly with respect to TARs, these findings are consistent with those from previous research studies (e.g. Connolly and Hyndman, 2001, 2004), which show a greater tendency for the UK charities to disclose performance compared to their RoI counterparts. This is despite the fact that, of late, much has been trailed in the RoI regarding the need to improve accountability and establish an effective regulatory process that promotes accountability issues (Burke-Kennedy, 2013; The Wheel, 2014; Breen and Carroll, 2015). Nevertheless, accountability and regulatory processes are considerably more long-standing and institutionalised in the UK (England and Wales has had a Charity Commission since 1853, compared to the establishment of CRA in the RoI in 2014) and the charity reporting framework has been more embedded. For example, the charities SORP has been effectively mandatory for large UK charities for a number of years; in contrast, it has been only (and remains at the time of writing - October 2017) best practice for RoI charities.

Each of the nine items shown in Table 3 (item (a)-(i)) is now discussed in turn.

\section{(a) Aims and objectives}

It is important that organisations explain why they exist and the changes they seek. All but one (a charity in the RoI) of the fifty charities provided details of their aims and objectives in their TAR, with the information typically being presented as a single overarching 'mission' or 'vision' supplemented by more detailed objectives. Each of the twenty charities publishing a separate annual review provided details of their aims and objectives in this document.

\section{(b) What activities does the organisation carry out to achieve its aims?}

It can be argued that charities should explain their aims and objectives (item (a)) and the activities undertaken to achieve those objectives (item (b)) to enable readers 
TABLE 3: PERFORMANCE ACCOUNTABILITY DISCLOSURES*

\begin{tabular}{|c|c|c|c|c|c|c|}
\hline & \multicolumn{2}{|c|}{ United Kingdom } & \multicolumn{2}{|c|}{ Republic of Ireland } & \multicolumn{2}{|c|}{ Total } \\
\hline & $\begin{array}{c}\text { Trustees' } \\
\text { Annual } \\
\text { Report } \\
(\mathbf{n}=\mathbf{2 5}) \\
\end{array}$ & $\begin{array}{l}\text { Annual } \\
\text { Review } \\
(n=16)\end{array}$ & $\begin{array}{c}\text { Trustees' } \\
\text { Annual } \\
\text { Report } \\
(\mathrm{n}=\mathbf{2 5}) \\
\end{array}$ & $\begin{array}{l}\text { Annual } \\
\text { Review } \\
(n=4)\end{array}$ & $\begin{array}{c}\text { Trustees' } \\
\text { Annual } \\
\text { Report } \\
(\mathbf{n}=\mathbf{5 0}) \\
\end{array}$ & $\begin{array}{l}\text { Annual } \\
\text { Review } \\
(n=20)\end{array}$ \\
\hline Objectives and activ & ities & & & & & \\
\hline (a) Aims and objectives & 25 (100\%) & $16(100 \%)$ & 24 (96\%) & $4(100 \%)$ & 49 (98\%) & $20(100 \%)$ \\
\hline $\begin{array}{l}\text { (b) What activities } \\
\text { does the organisation } \\
\text { carry out to achieve } \\
\text { its aims? }\end{array}$ & $24(96 \%)$ & $15(94 \%)$ & $25(100 \%)$ & $4(100 \%)$ & 49 (98\%) & $19(95 \%)$ \\
\hline Performance & & & & & & \\
\hline (c) Input & $6(24 \%)$ & $0(0 \%)$ & $2(8 \%)$ & I (25\%) & $8(16 \%)$ & I (5\%) \\
\hline (d) Output & $20(80 \%)$ & $8(50 \%)$ & II (44\%) & $3(75 \%)$ & $3 I(62 \%)^{\wedge \wedge}$ & II (55\%) \\
\hline (e) Impact & $23(92 \%)$ & $16(100 \%)$ & $20(80 \%)$ & $4(100 \%)$ & $43(86 \%)^{\wedge \wedge}$ & $20(100 \%)$ \\
\hline (f) Efficiency & $6(24 \%)$ & $9(56 \%)$ & $5(20 \%)$ & I $(25 \%)$ & II (22\%) & $10(50 \%)$ \\
\hline (g) Effectiveness & $8(32 \%)$ & I (6\%) & $0(0 \%)$ & $0(0 \%)$ & $8(16 \%)^{\wedge}$ & I (5\%) \\
\hline $\begin{array}{l}\text { (h) Future target } \\
\text { information }\end{array}$ & II (44\%) & $2(13 \%)$ & $6(24 \%)$ & I (25\%) & 17 (34\%) & $3(15 \%)$ \\
\hline (i) Lessons learned & $4(16 \%)$ & $3(19 \%)$ & $2(8 \%)$ & $0(0 \%)$ & $6(12 \%)$ & $3(15 \%)$ \\
\hline $\begin{array}{l}\text { Total of items disclosed } \\
\text { by all charities }\end{array}$ & 127 & 70 & 95 & 18 & 222 & 88 \\
\hline $\begin{array}{l}\text { Average number of } \\
\text { charities (percentage) } \\
\text { disclosing }\end{array}$ & $14.1 \mid(56 \%)$ & 7.78 (49\%) & $10.56(42 \%)$ & $2.00(50 \%)$ & $24.67(49 \%)$ & $9.78(49 \%)$ \\
\hline
\end{tabular}

*Provides data on the number (and percentages) of charities making at least one disclosure of each of the nine information types. Percentages are based on the number making at least one disclosure divided by the number of TARs or annual reviews. Averages are based on the summation of the numbers making disclosures divided by the number of TARs/annual reviews. For example, with the UK TARs, there are I 27 items of information disclosed when the disclosures for all nine information types are summed.This is divided by nine (the nine information types) to give the average disclosure of I4.II charities, with an average percentage of charities disclosing of 56 per cent (I4. I I divided by 25 TARs).

Statistical differences

${ }^{\wedge}$ Difference in disclosure between the UK and Rol charities in the TAR significant at the I per cent level.

$\wedge^{\wedge}$ Difference in disclosure between the UK and Rol charities in the TAR significant at the 5 per cent level.

to understand and assess the performance of the organisation. Indeed, the current SORP (Charity Commission and OSCR, 2014) encourages such disclosures. Only one (a UK charity) of the fifty charities did not describe the activities undertaken to achieve their objectives in their TAR; one RoI charity illustrated this graphically (not shown in Table 3). With respect to those charities producing an annual review 
(twenty charities), all but one (a UK charity) described the activities undertaken to achieve their objectives.

As discussed earlier and illustrated in Figure 1, performance may be viewed in terms of a production model that includes organisational input, output, impact, efficiency and effectiveness. The disclosure of these five items is reported in Table 3 (items (c)-(g)) and discussed in the following text. It has been argued that such disclosures are of distinctive importance as vehicles for delivering performance accountability (Hyndman and McConville, 2016, 2018).

\section{(c) Input}

This represents the resources used in providing the charity's service(s) (e.g. spending by activity or line item, volunteer hours). Eight (16 per cent) charities (UK - six (24 per cent); RoI - two (8 per cent)) provided input information in the narrative section of their TAR. Two provided such information in monetary terms (e.g. spending), while six provided it in non-monetary terms (e.g. staffing/volunteer levels) (detail not shown in Table 3). Only one charity (from the RoI) provided details of inputs consumed in delivering its services in its annual review.

\section{(d) Output}

This information relates to goods and services produced (e.g. number of tests/ inspections, number of people assisted or trained); it does not measure the impact upon clients or problems (Anthony and Young (2002) - 'process measures'). Thirtyone (62 per cent) charities (UK - twenty (80 per cent); RoI - eleven (44 per cent)) disclosed output information in their TAR; the difference in disclosure levels between the UK and RoI charities being statistically significant at the 5 per cent level. Eleven (55 per cent) charities (UK - eight (50 per cent); RoI - three (75 per cent)) disclosed output information in their annual review. Frequently, this information was presented in graphical form, both in TARs and annual reviews.

\section{(e) Impact}

Impact represents the difference that an activity makes to those the organisation is trying to help (e.g. change in percentage of the population in a particular area gaining employment, reaction to a service provision by those using it, personal stories). Forty-three (86 per cent) of the 50 charities (UK - twenty-three (92 per cent); RoI - twenty (80 per cent)) surveyed presented details of the impact of their activities in their TAR. Each of the charities publishing an annual review discussed the impact of their activities in such a document. Impact information, whether in TARs or annual reviews, often focused on the quality of the services provided.

\section{(f) Efficiency}

This type of information indicates the relationship between input and output (e.g. cost per person assisted, number of operations performed per doctor). Eleven (22 per cent) charities (UK - six (24 per cent); RoI - five (20 per cent)) provided information on efficiency in their TAR. The information disclosed was primarily presented in monetary terms; for example, ' 90 pence of every $£ 1$ received was spent directly on delivery services directly to beneficiaries'. Ten (50 per cent) of the twenty 
charities producing an annual review (UK - nine (56 per cent); RoI - one (25 per cent)) provided information on efficiency in such a communication. Again, this was primarily presented in monetary terms, with two (UK) charities presenting the details graphically (not shown in Table 3 ).

\section{(g) Effectiveness}

This represents the relationship between output and objectives (e.g. actual number of operations versus number of operations planned). In total, eight (16 per cent) charities (all UK-based) disclosed effectiveness information in their TAR (no RoI charity disclosed this information); the difference in disclosure levels between UK and RoI charities being significant at the 1 per cent level. Only one charity (a UK charity) provided effectiveness information in their annual review.

\section{(h) Future target information}

As future target information is required to subsequently assess future effectiveness (and give stakeholders a detailed, quantitative perspective of what the charity intends to do going forward), it can be argued that charities should provide this basis for comparison. In addition, it allows stakeholders, particularly donors/ funders, to get perspective on what any current donations are likely to be directed towards (as well as providing useful context) (Jackson, 1982; Charity Commission and OSCR, 2014). Seventeen (34 per cent) of the fifty charities (UK - eleven (44 per cent); RoI - six (24 per cent)) presented future target information (e.g. future development projects to be undertaken) in their TAR. Three (15 per cent) of the twenty charities (UK - two (13 per cent); RoI - one (25 per cent)) producing an annual review included future target information in such a document.

\section{(i) Lessons learned}

Ní Ógáin et al. (2012) posit that as part of a performance accountability framework, an organisation should, in addition to providing information in relation to the usual elements of a production process of service delivery, also provide details of any lessons learned from operations over the previous period(s). Such reflection, it is argued, can enhance learning and sharpen performance delivery in the future. Six (12 per cent) of the fifty charities (UK - four (16 per cent); RoI - two (8 per cent)) described in their TAR how the organisation had improved or changed as a result of its experiences; three provided such information in their annual review (15 per cent of the twenty charities utilising this communication channel).

\section{DISCUSSION AND CONCLUSION}

The UK and RoI charity sectors have grown significantly over time, and are continuing to grow. They have major economic, cultural and social impacts. To maintain confidence, and build trust, good accounting and reporting systems are essential. Indeed, such could be viewed as necessary conditions for the health and growth of these sectors. Well-developed and appropriate accounting and reporting systems can help charities discharge accountability to external stakeholders, as well 
as supporting internal mangers in making planning and control decisions that sharpen mission focus. Within such a framework, the importance of performance accountability and performance reporting is considerable. Indeed, in the charity sector, it is often argued that while financial accountability (e.g. through the provision of audited financial statements) is necessary, performance accountability (through telling the performance story via service delivery narratives and metrics - often in terms related to aims, outputs, impacts, efficiency and effectiveness) is paramount. Not only do the existence of such systems have the potential to discharge accountability for performance to external stakeholders (particularly in the case of donors/funders) in a manner consistent with a principal-agent relationship (Laughlin, 1990), but they also have the capacity to reduce the likelihood of scandals by requiring greater transparency, acting as 'sunlight' to provide positive illuminating and 'disinfectant' properties (Heald, 2006). Moreover, such systems can support the establishment and maintenance of legitimacy and trust with key external stakeholders, essential qualities required to attract and grow funding flows. This paper explores and compares performance reporting by large charities in both the UK and RoI (by considering performance disclosures in more formal TARs and, less formal, annual reviews) and analyses the results in the context of both accountability and legitimacy. Specifically it highlights, and comments on, the current state of charity performance reporting in each of these jurisdictions.

Before discussing the disclosure of performance information, it is worth noting that in this study of reporting practices there was evidence of the very limited use of annual reviews as a channel of communication by RoI charities. Only 16 per cent (four) of RoI charities surveyed published such a document compared with 64 per cent (sixteen) of the UK charities. Annual reviews, compared with annual reports (of which the TAR is an aspect): (i) are normally shorter, pithier publications that include some of the information in the annual report (but commonly in a more condensed form); (ii) are frequently written in less formal language; and (iii) often include a higher proportion of stories, photographs and diagrams. Notwithstanding cost considerations (which always come into play with any communications), annual reviews have been found to be more engaged with than TARs and, as such, provide greater general visibility (Connolly and Hyndman, 2013). Given that they 'connect' more with external stakeholders (particularly individual donors), a lack of utilisation of such formats in the RoI suggests a weaker accountability architecture in terms of donors.

Performance accountability disclosures address the impact of the organisation on society. As illustrated in Table 3, the disclosure of nine items ((a)-(i)) of performance-accountability information were collected and collated under two sub-headings: aims and objectives, and performance. The former (items (a) and (b)) incorporates the provision of information that enables readers to understand the aims and objectives set by the charity and the main strategies and activities undertaken to achieve them. Accordingly, on the basis of arguments consistently appearing in both recent iterations of the charities SORP and broader sector-wide debates and discussions, charities should explain their objectives, together with an explanation and review of the significant activities undertaken in pursuit of the achievement of those objectives. More specific (and often measurable) performance 
information (items (c)-(g)) includes an analysis of organisational input, output, impact, efficiency and effectiveness, with complementary future target information (item (h)) and lessons learned (item (i)) being potentially useful to stakeholders in assessing both direction of travel in terms of performance reporting and the challenges of delivering performance.

On the whole, the average percentage of the UK and RoI charities providing performance-accountability disclosures in both their TARs and annual reviews was low. The overall average disclosure rate by the fifty charities surveyed (twenty-five UK, twenty-five RoI) of the nine information types used in this analysis was slightly below 50 per cent (Table 3, items (a)-(i)). Moreover, it is noteworthy that with respect to the seven items of information that focused more on the 'calculation' of performance (Table 3, items (c)-(i)), the percentage of UK and RoI charities disclosing this information was even lower (both in the TARs and the annual reviews). Looking at the disclosure of the nine items (Table 3, items (a)-(i)) in the TARs and annual reviews more closely reveals that a higher percentage of charities provided the information in the TARs with respect to five of the items (items (b), (c), (d), (g) and (h)), of which four represent the 'performance' aspect of the disclosures (items (c), (d), (g) and (h)). The percentage disclosure levels were higher in the annual reviews for four items (items (a), (e), (f) and (i)), of which three fell under the 'performance' category (items (e), (f) and (i)). Given the importance of performance-accountability disclosures, and allowing for the fact that there are many difficulties experienced by charities in seeking to measure and report performance, the results suggest weak performance accountability. As a consequence, the relevance of reporting via TARs and annual reviews can be questioned, as can be the extent to which such documents support the building of a charity's legitimacy in the eyes of the wider world. For example, a significant proportion of charities reported no information on effectiveness and efficiency, two crucial criteria for judging performance (and key information viewed as important to stakeholders - Hyndman, 1990; Connolly and Hyndman, 2013). Such shortcomings can undermine trust and confidence in the sector, and damage reputation, which, ultimately, could impact on funding flows.

With respect to the provision of performance-accountability disclosures in the UK TARs compared with their RoI counterparts, a higher percentage of the UK charities disclosed eight of the nine performance items used in the analysis. Only item (b) (activities carried out) had higher disclosure for RoI charities (Table 3); although disclosure of this was extensive for all charities in both the UK and RoI. Moreover, a higher percentage of the UK charities provided each of the performance information items ((c)-(i)) compared with RoI charities, with the difference in the level of disclosure being significant at either the 1 per cent or 5 per cent level in three cases (items (d) output, (e) impact and (g) effectiveness). In relation to performanceaccountability disclosures in the UK and RoI annual reviews, the inter-jurisdictional comparisons were more similar, with RoI charities having higher average disclosure rates with four of the nine items (Table 3). However, the limited use of annual reviews as a communication channel in the RoI (with only four of the twenty-five RoI charities producing such a document) encourages caution in drawing definitive conclusions here. However, despite the caveats in relation to annual reviews, overall the results indicate much greater use of performance reporting in the UK. 
To an extent, this possibly reflects the greater engagement of the UK charities in such performance-accountability discussions (relating to SORP developments and contact with the Charity Commission over a number of years) and the greater presence and push for such reporting from the UK groups (such as Inspiring Impact, New Philanthropy Capital and the National Council for Voluntary Organisations). Due to the more undeveloped and less-regulated sector in the RoI (Breen and Carroll, 2015), such pressures have not been present to the same extent (not least because of the absence, until very recently, of a regulator).

Previous charity accounting research has indicated the critical nature of performance information in discharging accountability to stakeholders (Ebrahim, 2003; Dhanani, 2009; Hyndman and McConville, 2018). This is largely recognised by providers of information, but this alone does not appear to be a trigger for wide dissemination of such information (Hyndman, 1991). While difficulties in developing useful performance measurement and reporting systems by charities may provide some explanation for the limited reporting, other factors may have an impact. These include the desire or willingness of charities to report, the cost of reporting and the possible repercussions of highlighting poor performance (Thompson, 1995; Connolly and Hyndman, 2013). However, as discussed in this article, a lack of disclosure can weaken accountability, trust and legitimacy. Moreover, greater transparency of performance has the potential to keep a charity 'honest' and reduce the possibility of scandals (Hind, 2017). In addition, limited external reporting of performance (as is evidenced in this research) might indicate that performance information is unavailable internally to management, which may weaken their ability to plan and control effectively. It has been argued by some that managers in charities and, more widely, NFPOs may prefer limited performance reporting because they seek to avoid accountability (Eden and Hyndman, 1999; Connolly and Hyndman, 2004), although this argument ignores the commitment and professionalism of charity managers and the ethically founded desire of many in the sector to do the 'right thing' (Hind, 2011; Hyndman and McConville, 2018). Despite these caveats and challenges, there is a persuasive case (related to concepts of accountability, trust building and legitimacy) for greater endeavour by individual charities (and the sector more widely) in the development and use of more substantial charity performance measurement and reporting systems as a basis for meeting stakeholders information needs.

A number of researchers have stressed the idea that big donors/funders (largely because of their economic power) can more easily gain direct access to charities' performance information beyond that which is included in official documents such as the TAR (Gray, 1983; Hyndman and McConville, 2018). From a stakeholder theory perspective (Freeman, 1984; Hyndman and McDonnell, 2009), this study suggests that other stakeholders (including the general public) may be particularly interested (or this may, at least, be the charities' perception) in the actual activities carried out by the charity rather than any specific 'measurable' (or calculable) achievements. Such could be an influencing factor in terms of determining the content of TARs (and annual reviews). While these stakeholders may have difficulty in assessing and understanding (and in being emotionally affected by) specific efficiency and effectiveness indicators, they may be much more drawn to what a charity has actually done (particularly when it is presented in the form of a story). This might 
explain the more descriptive (rather than indicator-based) information provided in both jurisdictions. However, in addition to this, the disclosure of more-specific, numerical indicators (albeit that these often also rely on subjective judgement), may increase the potential for 'misread' and misinterpretation. Such disclosures, particularly when exploited by the media, may risk reputational damage. Therefore, there may be reluctance on the part of some charities to present such 'hostages to fortune' in public documents (despite any perceived or actual importance to stakeholders).

From an accountability and transparency point of view (Fry, 1995; Laughlin, 1996; Connolly and Hyndman, 2013), the results of this study also intimate that having a mandatory reporting system (however advanced) increases the likelihood of general disclosure. This is suggested by the UK case when compared to the RoI case. Although this research cannot comment on the actual use of information by stakeholders (this being beyond its scope), the UK charities, for which the SORP is mandatory by law, generally disclose more information and are more inclined to communicate it through different channels (such as that of annual reviews).

Of a more managerial concern, an important issue relates to the reliability of performance information that is disclosed externally. If no verification of the performance numbers reported by a charity is required, then there may be a temptation to present performance in a manner that is perceived as more acceptable to the reader, for example by exaggerating good performance, regardless of its accuracy. As external parties often use externally reported performance information to make judgements and decisions regarding a charity, there is a strong case for some degree of independent verification (perhaps similar to that which is imposed on financial accounting information i.e. disclosure requirements, external auditing and standard setting after consultation with interested parties). It should be noted that performance accountability disclosures analysed in this research have not been subject to independent verification (as is the case with such information reported by most of the NFPOs). However, with some charities, there is evidence that attempts have been made to provide stakeholders with the basis of the collection and analysis of the performance information as it is reported, presumably as a basis to improve their understanding (Hyndman and McConville, 2016).

With respect to possible further research, it is possible that differences in the extent of the reporting of performance information by charities may be influenced by the type of charities reporting. For example, some charities may have greater incentive to produce such information (e.g. charities operating on the fringe of the public sector), while other charities are demand led and may encounter greater difficulty in this regard (e.g. disaster relief charities). Such research could provide valuable additional understanding of the reason for reporting practices. Furthermore, research considering different sizes of organisation, different organisational forms, or charities engaged with particular causes or means of operation could identify (and explain) differences in performance reporting relating to such variables. This research identified weak accountability with respect to performance reporting, but (not being its focus) did not provide evidence regarding reasons for this. Qualitative research, possibly utilising interviews, might help to provide useful insights to help explain the reasons for the nature and extent of current reporting practices with respect to performance. 
A key theme of this paper is that good performance accountability supports the building of trust and legitimacy, and trust and legitimacy are essential to ensure the continuing health of the sector (including its ability to access funding). Conversely, poor performance accountability has the potential to undermine accountability; undermined accountability can damage trust and legitimacy, and damaged trust and legitimacy weakens the sector (and makes it more difficult to access funding). Therefore, good performance accountability is vital. To encourage the development and use of performance information, it would seem appropriate that charity-specific guidance should be provided by those concerned with the administration and control of the sector, both in the UK and RoI. This may include the various, more-established, charity regulators in the UK (Charity Commission, CCNI and OSCR) and the more-emerging CRA in the RoI. In particular with respect to the RoI, and reflecting the results of this study, moves to provide such steering would seem especially apposite. Indeed, given charities' expertise, focus and limited resource base, to expect individual charities (whether in the UK or RoI) to develop meaningful and extensive performance reporting systems without guidance (and perhaps regulatory backing) is perhaps too optimistic.

\section{ENDNOTES}

1 SORPs are recommendations on accounting practice for specialised industries or sectors, and they supplement other legal and regulatory requirements. Where a separate SORP exists for a particular class of charity (e.g. for the Further and Higher Education sector or Registered Social Landlords), those charities should adhere to that SORP. In the UK, the Charity Commission and OSCR are the joint SORP-making body for charities. Large UK charities must comply with the extant charities SORP, with compliance in RoI being considered best practice. At the time of writing (October 2017), the extant charities SORP is the 'FRS 102 SORP' (Charity Commission and OSCR, 2014).

2 In this article, the term 'annual report' is used to refer to the TAR and financial statements. This research, while recognising the importance of traditional financial statements, focuses on information contained in the TAR (i.e. excluding the financial statements). The term 'financial statements' is used in this context to include the statement of financial activities, balance sheet, statement of cash flows and related notes.

3 The SORP applies to all charities required to produce accruals accounts (unless a more specialised SORP applies to a particular class of charity). Company charities, irrespective of size, must prepare accruals accounts that give a true and fair view. In England, Northern Ireland, Scotland and Wales, the threshold at which accruals accounts must be produced by non-company charities is a gross annual income of more than $£ 250,000$. In the RoI, a charity with a gross annual income of $€ 10,001$ or more is required to prepare a profit and loss account (or income and expenditure account and statement of assets and liabilities) for the reporting period. 'Larger charities' is a term used in the FRS 102 Charities SORP to identify those charities with a gross income exceeding $£ 500,000$ or $€ 500,000$ in the reporting period.

4 See http://apps.charitycommission.gov.uk/ShowCharity/RegisterOfCharities/AdvancedSearch.aspx.

5 A copy of the checklist is available from the authors on request.

6 Given the small number of RoI charities producing an annual review, chi-square tests were not carried out to identify if there were significant differences in the number of UK and RoI charities reporting performance information in their annual reviews. 


\section{REFERENCES}

Accounting Standards Board (ASB) (1999). Statement of Principles for Financial Reporting, London: ASB.

ASB (2007). Statement of Principles for Financial Reporting: Interpretation for Public Benefit Entities, London: ASB.

Accounting Standards Committee (ASC) (1975). The Corporate Report, London: ASC.

ASC (1988). Accounting by Charities, Statement of Recommended Practice No. 2, London: ASC.

American Accounting Association (1989). Measuring the Performance of Non-profit Organisations: The State of the Art, Sarasota: American Accounting Association.

Anthony, R.N. and Young, D.W. (2002). Management Control in Non-Profit Organisations, 7th edn, New York, USA: McGraw Hill.

Ashford, J.K. (1989). 'Charity Accounts', in L.C.L. Skerratt and D.J. Tonkins (eds.), Financial Reporting 1989-90: A Survey of UK Reporting Practice, London: Institute of Chartered Accountants in England and Wales, pp. 23-48.

Austin, M. and Posnett, J. (1979). The Charity Sector in England and Wales - Characteristics and Public Accountability, National Westminster Bank Quarterly Review, Vol. August, No. 3, pp. 40-51.

Benjamin, L.M. (2012). The Potential of Outcome Measurement for Strengthening Nonprofits' Accountability to Beneficiaries, Nonprofit and Voluntary Sector Quarterly, Vol. 42, No. 6, pp. 1224-44.

Bird, P. and Morgan-Jones, P. (1981). Financial Reporting by Charities, London: Institute of Chartered Accountants in England and Wales.

Boardmatch Ireland (2013). Charity 100 index, December, available from: <http://www. boardmatchireland.ie/wp-content/uploads/2013/12/Final-Version-CI-100.pdf>, accessed 29 January 2016.

Boyne, G. and Law, J. (1991). Accountability and Local Authority Annual Reports: The Case of Welsh District Councils, Financial Accountability \& Management, Vol. 7, No. 4, pp. 179-194.

Brace, P., Elkin, R., Robinson, D. and Steinberg, H. (1980). Reporting of Service Efforts and Accomplishments (Research Report), Stamford, USA: Financial Accounting Standards Board.

Breckell, P., Harrison, K. and Robert. N. (2011). Impact Reporting in the UK Charity Sector, London: Charity Finance Group.

Breen, O.B. and Carroll, J. (2015). Giving in Ireland: A Nation of Givers in a Largely Unregulated Arena, in P. Wiepking and F. Handy (eds), The Palgrave Handbook of Global Philanthropy, Basingstoke, UK: Palgrave Macmillan, pp. 190-210.

Burke-Kennedy, E. (2013). Charity donations 'plummet 40\%' in wake of CRC revelations, December, available from: <http://www.irishtimes.com/news/social-affairs/charitydonations-plummet-40-in-wake-of-crc-revelations-1.1626936>, accessed 22 February 2017.

Cabinet Office (2002). Private Action, Public Benefit: A Review of Charities and the Wider Not-ForProfit Sector: Strategy Unit Report, London: Cabinet Office.

Carter N., Klein, K. and Day, P. (1992). How Organisations Measure Success: The Use of Performance Indicators in Government, London: Routledge.

Charities Aid Foundation (2001). Tell the Main Story: Guidance on Effective Annual Reporting, London: Charities Aid Foundation.

Charity Commission (2000a). Accounting and Reporting by Charities: Statement of Recommended Practice (SORP 2000), London: Charity Commission.

Charity Commission (2000b). Users on Boards: Beneficiaries who Become Trustees, London: Charity Commission.

Charity Commission (2004a). RS8: Transparency and Accountability, London: Charity Commission. Charity Commission (2004b). The Hallmarks of an Effective Charity, London: Charity Commission. 
Charity Commission (2005). Accounting and Reporting by Charities: Statement of Recommended Practice (SORP 2005), London: Charity Commission.

Charity Commission (2016). Charities in England and Wales, available from: <http://apps. charitycommission.gov.uk/showcharity/registerofcharities/SectorData/SectorOver view.aspx>, accessed 31 March 2016.

Charity Commission and Office of the Scottish Charity Regulator (OSCR) (2014). Charities SORP (FRS 102) Accounting and Reporting by Charities: Statement of Recommended Practice applicable to charities preparing their accounts in accordance with the Financial Reporting Standard applicable in the UK and Republic of Ireland (FRS 102) (effective 1 January 2015), London: Charity Commission and OSCR.

Charity Commission for Northern Ireland (2017). The 'Deemed' List of Northern Ireland Charities, available from: <http://www.charitycommissionni.org.uk/Our_regulatory_activity/ List_of_deemed_charities.aspx>, accessed 30 March 2017.

Connolly, C. and Dhanani, A. (2006). Accounting Narratives: The Reporting Practices of British Charities, Journal for Public and Nonprofit Services, Vol. 35, No. 1, pp. 39-62.

Connolly, C. and Dhanani, A. (2009). Research Report 109: Narrative Reporting by UK Charities, London: Association of Chartered Certified Accountants.

Connolly, C. and Hyndman, N. (2000). Charity Accounting: An Empirical Analysis of the Impact of Recent Changes, The British Accounting Review, Vol. 32, No. 1, pp. 77-100.

Connolly, C. and Hyndman, N. (2001). A Comparative Study of the Impact of Revised SORP 2 on British and Irish Charities, Financial Accountability \& Management, Vol. 17, No. 1, pp. 73-97.

Connolly, C. and Hyndman, N. (2002). The State of Charity Accounting in Ireland: A Study by Jurisdiction and Size, Irish Accounting Review, Vol. 9, No. 1. pp. 57-92.

Connolly, C. and Hyndman, N. (2003). Performance Reporting by UK Charities: Approaches, Difficulties and Current Practice, Edinburgh: Institute of Chartered Accountants of Scotland.

Connolly, C. and Hyndman, N. (2004). Performance Reporting: A Comparative Study of British and Irish Charities, British Accounting Review, Vol. 36, No. 2, pp. 127-154.

Connolly, C. and Hyndman, N. (2013). Towards Charity Accountability: Narrowing the Gap Between Provision and Needs?, Public Management Review, Vol. 15, No. 1, pp. 1-24.

Connolly, C. and Hyndman, N. (2017). The Donor-Beneficiary Charity Accountability Paradox: A Tale of Two Stakeholders, Public Money \& Management, Vol. 37, No. 3, pp. 157-164.

Connolly, C., Hyndman, N. and McConville, D. (2013). UK Charity Accounting: An Exercise in Widening Stakeholder Engagement, British Accounting Review, Vol. 45, No. 1, pp. 58-69.

Dhanani, A. (2009). Accountability of UK Charities, Public Money \& Management, Vol. 29, No. 3, pp. 183-190.

Ebrahim, A. (2003). Accountability in Practice: Mechanisms for NGOs, World Development, Vol. 31, No. 5, pp. 813-829.

Eden, R. and Hyndman, N. (1999). Performance Measurement in the UK Public Sector: Poisoned Chalice or Holy Grail?, Optimum: The Journal of the Public Sector, Vol. 29, No. 1, pp. 9-15.

Freeman, R.E. (1984). Strategic Management: A Stakeholder Approach, Boston: Pitman.

Fry, R.E. (1995). Accountability in Organisational Life: Problem or Opportunity for Nonprofits?, Nonprofit Management and Leadership, Vol. 6, No. 2, pp. 181-195.

Gambling, T., Jones, R., Kunz, C. and Pendlebury, M. (1990). Research Report 21: Accounting by Charities: The Application of SORP2, London: Association of Chartered Certified Accountants.

Goodman Committee (1976). Report on Charity Law and Voluntary Organisations, London: Bedford Square Press. 
Gray, R. (1983). Accounting, Financial Reporting and Not-for-Profit Organisations, AUTA Review, Vol. 15, No. 1, pp. 3-23.

Gray, R. (1984). Uncharitable View of Accounting, Accountancy, Vol. 94, No. 1096, p. 84.

Guthrie, J. and Parker, L. (1989). Corporate Social Reporting: A Rebuttal of Legitimacy Theory, Accounting and Business Research, Vol. 19, No. 76, pp. 343-353.

Heald, D. (2006). Transparency as an Instrumental Value, in C. Hood and D. Heald (eds), Transparency: The Key to Better Governance? Proceedings of the British Academy 135, Oxford: Oxford University Press.

Hedley, S., Keen, S., Lumley, T., Ní Ógáin, E., Thomas, J. and Williams, M. (2010). Talking About Results, London: New Philanthropy Capital.

Hind, A. (2011). Increasing Public Trust and Confidence in Charities: On the Side of the Angels, Public Money \& Management, Vol. 31, No. 3, pp. 201-205.

Hind, A. (2017). Fundraising in UK Charities: Stepping Back from the Abyss, Public Money \& Management, Vol. 37, No. 3, pp. 205-210.

Hines, A. and Jones, M.J. (1992). The Impact of SORP on the UK Charitable Sector: An Empirical Study, Financial Accountability \& Management, Vol. 8, No. 1, pp. 49-67.

HM Treasury (2011). HM Treasury and Department for Work and Pensions: Green Book discussion paper on valuing social impacts, London: HM Treasury.

Hyndman, N. (1990). Charity Accounting: An Empirical Study of the Information Needs of Contributors to UK Fundraising Charities, Financial Accountability \& Management, Vol. 6, No. 4, pp. 295-307.

Hyndman, N. (1991). Contributors to Charities - A Comparison of Their Information Needs and the Perceptions of Such by the Providers of Information, Financial Accountability $\mathcal{E}$ Management, Vol. 7, No. 2, pp. 69-82.

Hyndman, N. and Anderson, R. (1997). A Longitudinal Study of the Use of Performance Measures in the Annual Reports of UK Executive Agencies, The Irish Accounting Review, Vol. 4, No. 1, pp. 43-74.

Hyndman, N. and McConville, D. (2016). Transparency in Reporting on Charities' Efficiency: A Framework for Analysis, Nonprofit and Voluntary Sector Quarterly, Vol. 45, No. 4, pp. 844-865.

Hyndman, N. and McConville, D. (2018). Making Charity Effectiveness Transparent: Building a Stakeholder-Focused Framework of Reporting, Financial Accountability \& Management, Vol. 34, No. 1, pp. 1-15.

Hyndman, N. and McDonnell, P. (2009). Governance and Charities: An Exploration of Key Themes and the Development of a Research Agenda, Financial Accountability \& Management, Vol. 25, No. 1, pp. 5-31.

Inspiring Impact (2013). The Code of Good Impact Practice, London: National Council for Voluntary Organisations.

Jackson, P.M. (1982). The Political Economy of Bureaucracy, London: Philip Allan.

Jetty, J. and Beattie, V. (2009). Research Report 108: Charity Reporting - A Study of Disclosure Practices and Policies of UK Charities, London: Association of Chartered Certified Accountants.

Laughlin, R. (1990). A Model of Financial Accountability and the Church of England, Financial Accountability \& Management, Vol. 6, No. 2, pp. 93-114.

Laughlin, R. (1996). Principals and Higher Principals: Accounting for Accountability in the Caring Profession, in R. Munro and J. Mouritsen (eds), Accountability: Power, Ethos and the Technologies of Managing, London: International Thomson Business Press, pp. 225-244.

Lumley, T., Rickey, B. and Pike, M. (2011). Inspiring Impact: Working Together for a Bigger Impact in the UK Social Sector, London: New Philanthropy Capital.

Mayston, D. (1985). Non-Profit Performance Indicators in the Public Sector, Financial Accountability \& Management, Vol. 1, No. 1, pp. 51-74. 
McConville, D. (2017). Transparent Impact Reporting in Charity Annual Reports: Benefits, Challenges and Areas for Development, Public Money \& Management, Vol. 37, No. 3, pp. 211-215.

Mitchell, R.K., Agle, B.R. and Wood, D.J. (1997). Toward a Theory of Stakeholder Identification and Salience: Defining the Principle of Who and What Really Counts, Academy of Management Review, Vol. 22, No. 4, pp. 853-886.

Nevill, C. and Lumley, T. (2011). Measuring Together: Impact Measurement in the Youth Justice Sector, London: New Philanthropy Capital.

Ní Ógáin, E., Lumley, T. and Pritchard, D. (2012). Making an Impact: Impact Measurement among Charities and Social Enterprises in the UK, London: New Philanthropy Capital.

O'Brien, C. (2013). Former CRC Chief Executive Received €200,000 Lump Sum from Charitable Funds, available from <http://www.irishtimes.com/news/health/former-crc-chiefexecutive-received-200-000-lump-sum-from-charitable-funds-1.1624374>, accessed 22 February 2017.

Office of the Scottish Charity Regulator (2017). About OSCR, available from <http://www. oscr.org.uk/about-scottish-charities/>.

Palmer, P., Isaacs, M. and D'Silva, K. (2001). Charity SORP Compliance - Findings of a Research Study, Managerial Auditing Journal, Vol. 16, No. 5, pp. 255-262.

Pendlebury, M., Jones, R. and Karbhari, Y. (1994). Developments in the Accountability and Financial Reporting Practices of Executive Agencies, Financial Accountability \& Management, Vol. 10, No. 1, pp. 33-46.

Roberts, R. and Scapens, R. (1985). Accounting Systems and Systems of Accountability - Understanding Accounting Practices in Their Organisational Contexts, Accounting, Organizations and Society, Vol. 10, No. 4, pp. 443-456.

Stewart, J.D. (1984). The Role of Information in Public Accountability, in A.G. Hopwood and C.R. Tomkins (eds), Issues in Public Sector Accounting, London: Philip Allan.

Stone, M.M. and Ostrower, F. (2007). Acting in the Public Interest? Another Look at Research on Nonprofit Governance, Nonprofit and Voluntary Sector Quarterly, Vol. 36, No. 3, pp. 416-438.

The Wheel (2014). A Portrait of Ireland's Non-profit Sector, Dublin: The Wheel.

The W.K. Kellogg Foundation (2004). Using Logic Models to Bring Together Planning, Evaluation and Action: Logic Model Development Guide, Battle Creek, MI: The W.K. Kellogg Foundation.

Thompson, G.D. (1995) Problems with Service Performance Reporting: The Case of Public Art Galleries, Financial Accountability \& Management, Vol. 11, No. 4, pp. 337-350.

Williams, A. (1985). Performance Measurement in the Public Sector: Paving the Road to Hell?, Glasgow: University of Glasgow Publications.

Williams, S. and Palmer, P. (1998). The State of Charity Accounting - Developments, Improvements and Continuing Problems, Financial Accountability and Management, Vol. 14, No. 4, pp. 265-279. 